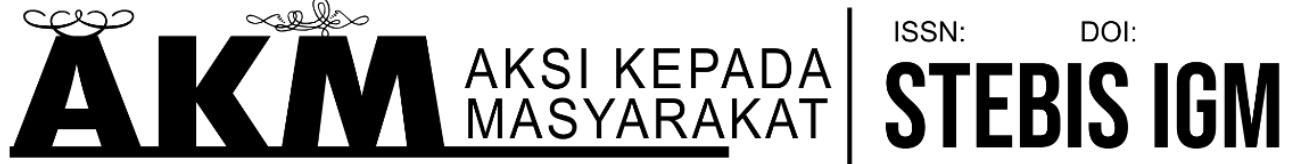 \\ Jurnal Pengabdian Kepada Masyarakat

\section{Sosialisasi 'Ariyah dalam Islam Di Kecamatan Air Kumbang Kabupaten Banyuasin}

\author{
${ }^{1}$ Saprida, ${ }^{2}$ Choiriyah \\ ${ }^{1}$ Program Studi Ekonomi Syariah STEBIS IGM Palembang \\ ${ }^{2}$ Program Studi Perbankan Syariah STEBIS IGM Palembang \\ Email : ida@ stebisigm.ac.id, choi@stebisigm.ac.id
}

\begin{abstract}
This community service activity discusses the introduction of ariyah or loans both from the definition of ariyah, the legal basis of ariyah, the pillars and conditions of ariyah, the types of ariyah, the responsibilities of the borrower, and the end of the ariyah contract. The purpose of this community service activity is to give an introduction about 'ariyah to recitation mothers in Nusa Makmur village with the aim of socialization participants to be able to know about the procedures for lending in Islamic law. Participants in socialization can also understand the importance of helping fellow human beings with help in helping kindness can bring the relationship of affection and love between Muslims. Giving loans to others in need is a rewarding worship, because it enters into the publicity of helping in goodness and piety.
\end{abstract}

Keywords : Socialization, Ariyah, Islamic Law

\begin{abstract}
Abstrak
Kegiatan pengabdian masyarakat ini membahas tentang pengenalan tentang 'ariyah atau pinjaman baik dari pengertian 'ariyah, dasar hukum 'ariyah, rukun dan syarat 'ariyah, macam-macam 'ariyah, tanggung jawab peminjam, dan berakhirnya akad 'ariyah. Tujuan kegiatan pengabdian masyarakat ini memberikan pengenalan tentang 'ariyah terhadap ibu-ibu pengajian di desa Nusa Makmur dengan tujuanan peserta sosialisasi bisa mengetahui tentang tata cara pinjaman dalam hukum Islam Peserta sosialisasi juga bisa memahami pentingnya melakukan tolong-menolong sesama manusia dengan adanya tolong-menolong dalam kebaikan dapat mendekatkan hubungan kasih sayang dan cintamencintai antara sesama Muslim. Memberikan pinjaman kepada orang lain yang membutuhkan merupakan ibadah yang membuahkan pahala, karena ia masuk ke dalam keumuman tolong-menolong dalam kebaikan dan takwa.
\end{abstract}

Kata Kunci: $\quad$ Sosialisasi, Ariyah, Hukum Islam

\section{Pendahuluan}

Secara semantik, Islam berasal dari kata salima artinya selamat dan menyelamatkan, damai dan untuk kedamaian, serta pasrah, tunduk dan patuh kepada Tuhan, dan dengan kepatuhan seseorang kepada Tuhannya, maka akan selamat dan akan mendapatkan keselamatan untuk melahirkan kedamaian bersama. Seorang Muslim adalah seorang yang dapat menyelamatkan sesamanya untuk mencapai kedamaian hidup bersama dengan patuh dan taat atas kebenaran ajaran Tuhannya (Asyari, 2015: 1). 
Islam adalah agama yang sempurna yang mengatur aspek kehidupan manusia, baik akidah, ibadah, ibadah, akhlak maupun muamalah. Salah satu ajaran yang sangat penting adalah bidang muamalah (ekonomi Islam). Ruang lingkup fiqh muamalah terbagi dua yaitu ruang lingkup muamlah yang bersifat adabiyah ialah ijab dan kabul, saling meridhai, tidak ada keterpaksaan dari salah satu pihak, hak dan kewajiban, kejujuran pedagang, penimbunan dan segala sesuatu yang berkaitan dengan peredaran harta dalam hidup bermasyarakat. Ruang lingkup yang bersifat madiyah yaitu mencakup segala aspek kegiatan ekonomi manusia, diantaranya tentang jual beli, pegadaian, penitipan, kerja sama pertanian, perdamaian bisnis dan tentang 'ariyah atau peminjaman (Mardani, 2016: 3).

Salah satu bentuk interaksi sosial dalam kehidupan sehari-hari adalah kegiatan pinjam-meminjam. Kegiatan yang sering dilakukan dalam keseharian hampir semua orang. Di saat setiap orang tidak selalu memiliki semua barang untuk memenuhi kebutuhannya, maka salah satu jalan keluarnya adalah dengan meminjamnya dari orang lain. Pinjam Meminjam merupakan bagian dari Muamalah, karena muamalah merupakan aturan yang mengatur hubungan manusia dengan manusia lainya untuk memenuhi kebutuhan hidupnya. Pinjam Meminjam merupakan salah satu bukti bahwa manusia akan selalu membutuhkan orang lain dalam memenuhi kebutuhan hidupnya.

\section{Metode Pengabadian}

1. Metode Pelaksanaan

Rangkaian kegiatan pengabdian masyarakat adalah sebagai berikut:

1) Bentuk Kegiatan

Bentuk kegiatan yang dilakukan dalam sosialisasi tersebut adalah :

$>$ Pemaparan materi tentang 'ariyah.

> Pemahaman dan tanya jawab tentang tata cara pinjaman yang benar dalam ajaran Islam.

2) Tempat Kegiatan

Adapun tempat kegiatan atau lokasi kegiatan dilaksanakan di lapangan Masjid desa Nusa Makmur.

3) Proses Kegiatan

Adapun proses kegiatan dilaksanakan dalam waktu 2 hari pada hari Sabtu dan Minggu mulai tanggal 03-04 Agustus 2019. Adapun kegiatan yang dilakukan selama kegiatan berlangsung adalah sebagai berikut :

a. Tanggal 03 Agustus 2019 :

Adapun kegiatan yang dilakukan pada pertemuan ke-1 adalah sebagai berikut :

1) Registrasi peserta

2) Penyampaian materi sesi I oleh Saprida, M.H.I. dengan judul materi pengertian 'ariyah dan rukun serta syarat 'ariyah.

3) Penjelasan dalil tentang 'ariyah dan macam-macam 'ariyah yang disampaikan oleh Choiriyah, S.H.I., M.Pd.I.

b. Tanggal 04 Agustus 2019:

Dilaksanakan pada pertemuan ke-2 adalah sebagai berikut :

1) Menyampaikan materi sesi II dilakukan oleh Saprida, M.H.I dengan judul materi hak dan kewajiban peminjam dan manfaat serta tujuan 'ariyah.

2) Penjelasan waktu pengembalian barang pinjaman yang dibawakan oleh Choiriyah, S.H.I., M.Pd.I. 
3) Tanya jawab 'ariyah dalam pandangan Islam.

4) Doa dan penutup yang dibawakan oleh Choiriyah, S.H.I., M.Pd.I.

\section{Waktu Kegiatan dan Materi Pokok dalam Kegiatan}

Pelaksanaan kegiatan dilakukan dalam waktu dua hari pada hari Sabtu dan Minggu Adapun jadwal pelaksanaannya adalah sebagai berikut :

Tanggal 03 Agustus 2019

\begin{tabular}{|l|l|l|}
\hline \multicolumn{1}{|c|}{ Waktu } & \multicolumn{1}{|c|}{ Materi } & \multicolumn{1}{c|}{ Narasumber } \\
\hline $09.00-09.30$ & - Registrasi peserta & - M. Fandi Syahriah \\
\hline $09.30-10.00$ & - Pembukaan & - M. Fandi Syahriah \\
\hline $10.00-11.00$ & $\begin{array}{l}\text { Materi: } \\
\text { - Pengertian 'ariyah }\end{array}$ & - Saprida, M.H.I \\
\hline $11.00-12.00$ & - Dalil tentang'ariyah & - Choiriyah, S.H.I.,M.Pd.I. \\
\hline $12.00-13.00$ & \multicolumn{2}{|c|}{ ISOMA } \\
\hline $13.00-14.00$ & $\begin{array}{l}\text { Materi: } \\
\text { - Rukun dan syarat 'ariyah }\end{array}$ & - Saprida, M.H.I \\
\hline $14.00-15.00$ & - Macam-macam 'ariyah & - Choiriyah, S.H.I.,M.Pd.I. \\
\hline
\end{tabular}

Tanggal 04 Agustus 2019

\begin{tabular}{|c|l|l|}
\hline \multicolumn{1}{|c|}{ Waktu } & \multicolumn{1}{|c|}{ Materi } & \multicolumn{1}{c|}{ Narasumber } \\
\hline $09.00-10.30$ & $\begin{array}{l}\text { Materi: } \\
\text { - Hak dan Kewajiban } \\
\text { Peminjam }\end{array}$ & - Saprida, M.H.I \\
\hline $10.30-12.00$ & $\begin{array}{l}\text { - Waktu Pengembalian } \\
\text { Barang Pinjaman }\end{array}$ & - Choiriyah, S.H.I.,M.Pd.I. \\
\hline $12.00-13.00$ & \multicolumn{2}{|c|}{ ISOMA } \\
\hline $13.00-14.00$ & $\begin{array}{l}\text { Materi: } \\
\text { - Manfaat dan tujuan 'ariyah }\end{array}$ & - Saprida, M.H.I \\
\hline $14.00-15.00$ & - Doa dan penutup & - Choiriyah, S.H.I.,M.Pd.I. \\
\hline
\end{tabular}

Total durasi pelaksanaan pengabdian pada masyarakat untuk masing-masing pelaksana adalah :

\begin{tabular}{|c|l|c|l|c|}
\hline No & \multicolumn{1}{|c|}{ Nama } & NIDN/NPM & \multicolumn{1}{c|}{ Status } & Durasi \\
\hline 1 & Saprida, M.H.I & 2114118401 & Dosen Ekonomi & 36 Jam \\
\hline 2 & Choiriyah, S.H.I.,M.Pd.I. & 2123068201 & Dosen Perbankan & 36 Jam \\
\hline 3 & M. Fandi Syahriah & 201601012 & Mahasiswa & 1 Jam \\
\hline
\end{tabular}

\section{Hasil dan Pembahasan}

\section{Materi Sosialisasi}

\section{a. Pengertian Ariyah}

Pinjaman atau 'ariyah menurut bahasa ialah pinjaman. Sedangkan menurut istilah menurut Hanafiyah adalah pemilikan manfaat secara cuma-cuma. Menurut Malikiyah 'ariyah adalah pemilikan manfaat dalam waktu tertentu dengan tanpa imbalan. Sedangkan Syafi'iyah, 'ariyah adalah kebolehan mengambil manfaat dari seseorang yang membebaskannya, apa yang mungkin untuk dimanfaatkan, serta tetap zat barangnya supaya dapat dikembalikan kepada pemiliknya. 
Selanjutnya 'ariyah menurut Hanabilah ialah kebolehan memanfaatkan suatu zat barang tanpa imbalan dari peminjam atau yang lainnya. Sedangkan menurut AlMawardi memberikan manfaat-manfaat (Suhendi, 2016: 92).

Menurut Amir Syarifuddin berpendapat, bahwa 'ariyah adalah transaksi atas manfaat suatu barang tanpa imbalan, dalam arti sederhana 'ariyah adalah menyerahkan suatu wujud barang untuk dimanfaatkan orang lain tanpa adanya imbalan. Menurut Ibnu Rif'ah 'ariyah adalah kebolehan mengambil manfaat suatu barang dengan halal serta tetap zatnya, supaya dapat dikembalikan kepada pemiliknya (Ghazaly, 2010: 247). Berdasarkan pengertian-pengertian di atas dapat disimpulkan pinjaman atau 'ariyah adalah memberikan manfaat sesutu barang dari seseorang kepada orang lain secara cuma-cuma. Jika digantikan dengan sesuatu atau ada imbalannya, maka tidak dapat dikatakan 'ariyah.

\section{b. Rukun dan Syarat 'ariyah}

Adapun yang menjadi rukun dan syarat 'ariyah adalah sebagai berikut:

1) Adanya pihak yang meminjamkan dengan syarat orang yang berakal sehat serta mengerti akad, maksud dan tujuan dari perbuatan yang dilakukan.

2) Adanya pihak yang dipinjamkan, dengan syarat orang yang berakal sehat serta mengerti mengerti maksud dan tujuan dari perbuatan yang dilakukan. Ia berhak atas barang yang dipinjamkan, barang itu dapat dimanfaatkan sesuai syariat Islam.

3) Adanya objek yang dipinjamkan dengan syarat:

$>$ Harta yang dipinjamkan harus milik atau harta yang berada di bawah kekuasaan pihak yang meminjamkan.

$>$ Objek yang dipinjam haruslah sesuatu yang bisa dimanfaatkan, baik kemanfaatan yang akan diperoleh itu berbentuk materi ataupun tidak.

4) Terjadi akad pinjam-meminjam (ijab kabul) (Mardani, 2016: 328).

\section{c. Dalil Hukum 'ariyah}

Menurut Sayyid Sabiq, tolong menolong ('ariyah) adalah sunnah. Adapun landasan hukumnya sebagai berikut:

1) Al-Qur'an

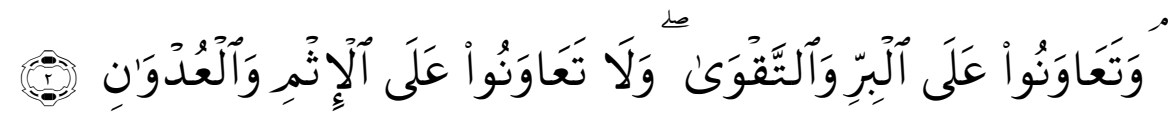

Artinya: "Dan tolong-menolonglah kamu dalam (mengerjakan) kebajikan dan takwa, dan jangan tolong-menolong dalam berbuat dosa dan permusuhan" (Al-Maidah : 2).

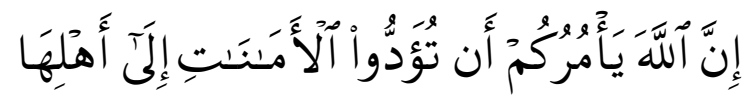

Artinya: "Sesungguhnya Allah memrintahkan kamu agar menyampaikan amanat kepada yang berhak menerimanya" (Al-Nisa: 58).

2) As-Sunnah

Rasulullah Saw bersabda, "Pinjaman yang tidak berkhianat tidak berkewajiban mengganti kerugian dan orang yang menerima titipan yang tidak khianat tidak berkewajiban mengganti kerugian". (HR. Daruquthni).

Rasulullah Saw bersabda, "Siapa yang meminjam harta manusia dengan kehendak membayarnya maka Allah akan membayarnya, barang siapa yang 
meminjam hendak melenyapkannya, maka Allah akan melenyapkan hartanya". (HR. Bukhari) (Suhendi, 2016: 94).

Ada beberapa hal yang menyebabkan hukum 'ariyah menjadi wajib, sunnah sebagai berikut :

1. Meminjamkan sesuatu hukumnya sunnah, terkadang pula menjadi wajib seperti meminjamkan sampan untuk menyelamatkan yang akan hanyut. Terkadang haram meminjamkannya seperti meminjamkan rumah untuk perzinahan.

2. Orang yang meminjam sewaktu-waktu boleh meminta kembali barang yang dipinjam oleh orang lain.

3. Sesudah yang meminjam mengetahui bahwa yang meminjamkan sudah memutuskan akadnya, ia tidak boleh memakai barang yang dipinjamnya.

4. Pinjam-meminjam tidak berlaku dengan matinya atau gilanya salah seorang dari peminjam atau yang meminjamkan (Nurhayati dan Sinaga, 2018: 174).

\section{d. Macam-macam 'Ariyah}

Menurut ulama Hanafiyah 'ariyah terbagi pada empat macam, yaitu:

1) 'Ariyah mutlaqah, yaitu pinjam meminjam yang tidak dikaitkan atau dibatasi oleh waktu dan cara pemanfaatannya. Misalnya, seseorang berkata : "Saya pinjamkan rumah saya ini kepada anda", tanpa mengaitkan dengan waktu dan batas pemanfaatan. Pembagian ini berimplikasi pada bebasnya peminjam untuk memanfaatkan 'ariyah.

2) 'Ariyah muqayyadah adalah pinjam-peminjam yang dikaitkan dengan waktu dan cara pemanfaatan. Misalnya, seseorang berkata: "Saya pinjamkan rumah saya ini kepada engkau selama 1 bulan dan dimanfaatkan hanya untuk memelihara barang.

3) 'Ariyah yang dibatasi waktu pemanfaatan. Namun, ia bebas dalam cara pemanfaatan. Misalnya, seseorang berkata: 'Saya pinjamkan rumah ini kepada anda selama 1 tahun. Namun, tidak dibatasi cara pemanfaatannya.

4) 'Ariyah yang dibatasi cara pemanfaatan, namun tidak dibatasi waktu pemanfaatannya. Dalam pembagian ini, peminjam tidak boleh memanfaatkan barang pinjaman menurut ketentuan yang ditetapkan pemilik barang.

5) Malikiyah dan Syafi'iyah membagi 'ariyah pada dua bentuk, yaitu mutlaqah dan muqayyadah saja (Rozalinda, 2016: 172).

\section{e. Tanggung Jawab Peminjam}

Bila peminjam telah memegang barang-barang pinjaman, kemudian barang tersebut rusak, ia berkewajiban menjaminnya, baik karena pemakaian yang berlebihan maupun karena yang lainnya. Demikian menurut Ibn Abbas, Abu Hurairah, Syafi'i, dan Ishaq dalam hadis yang diriwayatkan oleh Samurah, Rasulullah bersabda yang artinya:

"Pemegang berkewajiban menjaga apa yang ia terima, hingga ia mengembalikannya".

Sementara para pengikut Hanafi dan Maliki berpendapat bahwa, peminjam tidak berkewajiban menjamin barang pinjamannya, kecuali karena tindakannya berlebihan, karena Rasulullah bersabda: 
"Pinjaman yang tidak berkhianat tidak berkewajiban mengganti kerugian dan orang yang menerima titipan yang tidak khianat tidak berkewajiban mengganti kerusakan”. (dikeluarkanal-Daruquthni) (Suhendi, 2016: 98).

Menurut Hanafiyah, Syafi'iyah dan Hanabalah, kepemilikan barang yang ada pada pada diri musta'ir (orang yang meminjam) bersifat tidak lazim, karena merupakan kepemilikan tanpa adanya konpensasi, seperti halnya hibah. Mu'ir (orang yang meminjamkan) memiliki hak untuk merujuk barangnya dalam akan 'ariyah, begitu juga musta'ir memiliki hak untuk mengembalikan barang sepanjang ia mau. Menurut Malikiyah, mu'ir tidak memiliki hak untuk merujuk 'ariyah, sebelum musta' ir memanfaatkan 'ariyah. Jika 'ariyah dibatasi dengan waktu, mu' ir tidak boleh merujuk sebelum batas waktu berakhir (Djuwaini, 2010; 270).

\subsection{Meminjam Pinjaman dan Menyewakannya}

Abu Hanifah dan Malik berpendapat bahwa peminjam boleh meminjamkan benda-benda pinjaman kepada orang lain. Sekalipun pemiliknya belum mengizinkannya jika penggunaannya untuk hal-hal yang tidak berlainan dengan tujuan pemakaian pinjaman. Menurut mazhab Hambali, peminjam boleh memanfaatkan barang pinjaman atau siapa saja yang menggantikan statusnya selama peminjaman berlangsung, kecuali jika barang tersebut disewakan. Haram hukumya menurut Hambaliyah menyewakan barang pinjaman tanpa seizin pemilik barang. Jika peminjam suatu benda meminjamkan benda tersebut kepada orang lain, kemudian rusak di tangan kedua, maka pemilik berhak meminta jaminan kepada salah seorang di antara keduanya. Dalam keadaan seperti ini, lebih baik pemilik arang meminta jaminan kepada pihak kedua karena dialah yang memegang ketika barang itu rusak (Mardani, 2016: 330).

\subsection{Berakhirnya Akad 'Ariyah}

'Ariyah berakhir disebabkan oleh sebagai berikut :

a. Salah satu pihak menjadi tidak lagi cakap hukum untuk melakukan akad 'ariyah.

b. Diketahui bahwa salah satu pihak atau kedua belah pihak tidak tasharruf.

c. Adanya penipuan terhadap keadaan barang.

d. Barang dikendalikan oleh yang meminjam (Mardani, 2016: 329).

\section{Hasil Sosialisasi}

Dari sosialisasi yang telah narasumber dan panitia lakukan kepada para Ibuibu pengajian, diharapkan para peserta dapat memahami materi 'ariyah dalam Islam yang meliputi pengertian 'ariyah, dalil tentang 'ariyah, rukun dan syarat 'ariyah, macam-macam 'ariyah, hak dan kewajiban peminjam, waktu pengembalian barang pinjaman, manfaat dan tujuan 'ariyah yang telah diberikan oleh narasumber dan panitia. Dengan kegiatan tersebut semoga narasumber dan peserta mendapat wawasan tentang 'ariyah dalam Islam diantaranya sebagai berikut :

1. Peserta bisa memahami materi tentang 'ariyah dalam Islam yang meliputi pengertian pengertian 'ariyah, dalil tentang 'ariyah, rukun dan syarat 'ariyah, macam-macam 'ariyah, hak dan kewajiban peminjam, waktu pengembalian barang pinjaman, manfaat dan tujuan 'ariyah.

2. Para peserta bisa memahami 'ariyah yang benar untuk meningkatkan kesejahteraan bagi seluruh masyarakat. 
3. Menambah wawasan para peserta tentang 'ariyah yang benar dalam Islam.

4. Para peserta dapat menerapkan bahwa ariyah mempunyai tujuan dan manfaat yang besar bagi penerima peminjam dan yang memberi pinjaman.

5. Narasumber selalu mendalami tentang materi-materi yang dibawakan ketika sosialisasi.

\section{Simpulan}

Berdasarkan beberapa kegiatan yang telah narasumber beserta panitia lakukan pada pengabdian masyarakat tentang 'ariyah dalam Islam di lapangan Masjid Desa Nusa Makmur Kecamatan Air Kumbang maka dapat diambil beberapa kesimpulan :

1. Kegiatan ini sangat bermanfaat bagi peserta sosialisasi 'ariyah dalam Islam di lapangan Masjid Desa Nusa Makmur Kecamatan Air Kumbang, mereka membutuhkan tambahan pengetahuan tentang penerapan tata cara 'ariyah yang benar dalam Islam.

2. Kegiatan ini juga membantu para peserta sosialisasi tentang macam-macam 'ariyah yang benar dalam Islam.

3. Meninggalkan kecurangan-kecurangan dalam pelaksanaan 'ariyah untuk meningkatkan perekonomian yang benar dalam ajaran Islam.

4. Para peserta sosialisasi juga mengerti tentang waktu pengembalian barang pinjaman.

5. Peserta sosialisasi bisa mengerti tentang manfaat dan tujuan 'ariyah.

\section{Daftar Pustaka}

Asy'arie, Musa. 2015. Filsafat Ekonomi Islam. Yogyakarta: LESFI.

Djuwaini, Dimyauddin. 2010. Pengantar Fiqh Muamalah. Yogyakarta : Pustaka Pelajar.

Mardani. 2016. Fiqh Ekonomi Syariah . Jakarta : Kencana.

Suhendi, Hendi. 2016. Fiqih Muamalah. Jakarta: Rajawali Pers.

Ghazaly, Abdul Rahman dkk. 2010. Fiqh Muamalat. Jakarta: Kencana.

Nurhayati dan Ali Imran Sinaga. 2018. Fiqh dan Ushul Fiqh. Jakrta: Kencana.

Rozalinda. 2016. Fiqih Ekonomi Syariah: Prinsip dan Implementasinya pada Sektor Keuangan Syariah. Jakarta: Rajawali Pers. 
Susialisasi 'Ariyah dalam Islam

Di Kecamatan Air Kumbang Kabupaten Banyuasin

Saprida, Choiriyah 